\title{
The Asian Infrastructure Investment Bank and How China is Financing BRI
}

\author{
Peizhong Chen ${ }^{1,}{ }^{*}, \dagger$, Yina Zhou ${ }^{2, \dagger}$ \\ ${ }^{1}$ College of Agricultural and Environmental Sciences, University of California, Davis, Davis, 95616, \\ United States \\ ${ }^{2}$ Department of Economics, University of Connecticut, Storrs, 06269, United States \\ ${ }^{*}$ Corresponding author. Email: ynazhou@ucdavis.edu \\ tThese authors contributed equally
}

\begin{abstract}
Asian countries and regions have dedicated to the development of international economy and infrastructure establishment, among which China is endeavoring to make contributions and take actions to the sustainable development of international economic system. This article studies the history, current situation, and future prospects of the relationship and projects between the Asian Infrastructure Investment Bank (AIIB) and the Belt and Road Initiative under COVID-19. It analyses the projects that the AIIB has participated in the Belt and Road Initiative and evaluates the impact of each country's policies. It puts forward the construction investment of the Belt and Road Initiative in which some different countries and regions cooperate and participate in. The results enumerates some problems encountered in the development process such as tariff barriers, trade barriers, and political factors, and analyses the corresponding solutions based on this.
\end{abstract}

Keywords: Asian economic development; the Belt \& Road Initiative; infrastructure; international economic system.

\section{Introduction}

\subsection{Background}

The Asian Infrastructure Investment Bank (AIIB) is a multilateral development bank. It aims to improve economic and social outcomes in the Asia area. Currently, it has 103 members, including 16 members from around the world. After the agreement entered into force on 25 December 2015, the bank started operation after ratifications receiving from 10 member states holding a total number of $50 \%$ of the initial subscriptions of the Authorized Capital Stock. The proposal for creating an "Asian Infrastructure Investment Bank" was first made by the Vice Chairman of the China Center for International Economic Exchanges, a Chinese thinktank, at the Bo' ao Forum in April 2009. The initial context was to better use Chinese foreign currency reserves in the wake of the global financial crisis.

The Belt and Road Initiative (BRI), known in Chinese and formerly in English as One Belt One Road or BRI for short, is a global infrastructure development strategy adopted by the Chinese government in 2013 to invest in nearly seventy countries and international organizations. It is considered a centerpiece of Chinese Communist Party (CCP) general secretary and Chinese leader Xi Jinping's foreign policy. They initially announced the "Silk Road Economic Belt" strategy during an official visit to Kazakhstan in September 2013[1]. BRI proposed overland routes for road and rail transportation through Central Asia along the Western Regions famed historical trade routes, referring to the Indo-Pacific Sea routes through Southeast Asia to South Asia, the Middle East, and Africa. Examples of Belt and Road Initiative infrastructure investments include ports, skyscrapers, railroads, roads, airports, dams, and railroad tunnels. A 2018 study conducted by global economic consultants CEBR illustrated that BRI boosts world GDP by $\$ 7.1$ trillion per year by 2040 [5].

\subsection{Related Research}

Callaghan and Hubbard's research shows that with the fantastic boost in economy and political status, China is playing a positively influential role in international affairs, especially in regional 
development and multilateral cooperation. Inspired by the ancient Silk Road, China established AIIB and redefined its connotation by proposing "Silk Road economic belt" and "21st century maritime Silk Road" initiatives for multilateral cooperation in economy, policymaking, regional development, and international leadership. The AIIB will serve as a multilateral institution for China to learn from successful experience as well as benefit the international financial world [2]. Indeed, according to the study made by Rahul Mishra, the AIIB has performed its remarkable impact on developing Asian economic system and international economy and politics, which also established China's prominent role in global sustainable development and better economic promotion. However, according to data estimation, difficulties and obstacles that impede multilateral cooperation and regional economy are still infrastructure gaps existing in AIIB, which cannot be solved merely by one country. As a result, it is significant for AIIB to make accurate decision on selecting projects in order to make full use of the available financial, environmental, and other resources [3]. In addition, Ren illustrates that how China is developing the AIIB. Under the new leadership of China, there came up transition in the office accomplished in March 2013. Good infrastructure, political stability, good administration, and US Asia rebalance policy played a great role in its success over other Asian countries. Despite China initiating the new institution, it had no experience running it but was supported by other countries in launching it. This was possible because China had joined most of the international organizations and the fact that the institution brought a lot of international benefits AIIB has greatly helped China's economic development compared to other countries making it the second-largest economy and creating more political privileges [4]. Also, Ohashi states that it would play a major role in the country's opening-up. There was a great need for joining international organizations for the sake of gaining more recognition and respect. In 1996 China secured major agreements, which led to greater recognition in WTO by 2001 where the country just needed to be part of the leadership and didn't aim at reforming the system. The major purposes of the initiative are eradicating overloading, the renaissance of the local economy, and promoting neighborhood mediation. Major banks such as the New Development Bank finance this initiative [5]. For more details of this plan, Chan, Dai, Wang, and Lacka explore two parts of the initiative, which are the Silk Road Economic Belt (SREB) and the 21st Century Maritime Silk Road (MSR). These parts aim to connect China with the rest of the world, which creates the need to develop infrastructure in those parts. The initiative will impact the management of the global chain in both the entities of the supply chain as well as in the flow of the supply chain. Currently, studies on the BRI major in its economic development approach in optimizing plans logically and with experimental studies, analytical methods, and mathematics. One of the major benefits of the initiative would be bringing political stability, especially in insecure countries [6].

\subsection{Objective}

In general, the AIIB has played a very important role in the One Belt One Road project, not only raising funds, but also promoting the development of various projects. Various projects including multinational cooperation projects have also promoted the development of the Belt and Road Initiative. Although tariff barriers, trade barriers, and political factors exist, there are reasonable ways to solve them. Generally speaking, the development prospects of the AIIB and the Belt and Road Initiative are still very positive.

\section{Roles of Participants}

The AIIB and the BRI are twin brothers. The BRI with infrastructure construction at its core cannot implement without the promotion of the AIIB. Infrastructure construction requires a large amount of capital investment, which is difficult for a single country to complete. The establishment of the AIIB can be promoted. The primary concern of the "Belt and Road" is infrastructure investment. This is because developed countries generally face infrastructure transformation and upgrading, and developing countries face heavy tasks such as construction and replacement. This is more powerful 
than the so-called reindustrialization - the growth path of the world's real economy. The huge infrastructure investment gap is the root cause of such global effects of the Asian Infrastructure Investment Bank and the "One Belt One Road" initiative. In the process of promoting the "Belt and Road" construction, finance is the primary consideration, playing a guiding role in adjusting resource allocation and optimizing investment effects. The AIIB is the first multilateral financial institution proposed by China to operate according to the model and principles of multilateral development banks, focusing on supporting infrastructure construction in Asia.

On the one hand, the AIIB can deepen political, economic, and trade cooperation between countries. On the other hand, it can provide an essential source of funding and guarantee for the "Belt and Road" infrastructure construction." The relationship between the AIIB and the "Belt and Road Initiative" is cross-functional and not subordinate to each other. The Belt and Road Initiative is mainly a global strategy, including infrastructure, railways, etc., and the establishment of the AIIB is providing financial support for these infrastructure constructions. Therefore, the two seemingly unrelated things are the strategic service of the Asian Investment Bank for the Belt and Road Initiative. Promote public and private capital investment in the region's development, especially the development of infrastructure and other productive sectors. Use its disposable funds to provide financing support for the region's development, including projects and plans that can most effectively support the harmonious development of the overall economy in the region, and pay special attention to the needs of underdeveloped members in the region. Encouraging private capital to participate in investment is conducive to regional economic development. Especially projects, enterprises, and activities for developing infrastructure and other productive areas, and supplement private investment when private capital financing cannot be obtained under reasonable conditions. Other activities and services are provided to strengthen these functions. The 2020 new crown epidemic will undoubtedly disrupt the investment and business activities of Chinese companies related to the "Belt and Road", but as the epidemic is gradually brought under control, the "Belt and Road" foreign investment and trade activities have exceeded the level before the epidemic, and foreign contracting the engineering business is also beginning to show signs of recovery. However, this sign of recovery has not been priced by the market, and the company's qualifications and growth are still investors' biggest concerns about the underlying assets. The marginal change that needs to be recognized is that, in the context of the sharp appreciation of the renminbi, the People's Bank of China has therefore raised the upper limit of overseas lending by domestic companies and encouraged Chinese companies to "go global". It has noticed that the main macro factors restricting the "Belt and Road" after 2017 are: the obstruction of RMB internationalization and capital outflow, and the changes in the US Trump administration's China policy. The transformation of the above two major macro factors has become the basis for the future return of the "Belt and Road", which will be gradually verified in the control of the epidemic and the recovery of the global economy. Under a very low growth expectation implied by a valuation, any marginal change may bring about the elasticity of asset prices.

In 2020, the investment and trade of the "Belt and Road" will recover quickly, and the construction of the project needs to be controlled by the epidemic. The trade index of the Belt and Road has surpassed the epidemic level and reached a record high; the freight index can also confirm the strength of trade activities: in addition to the crude oil freight index, which is still at a historical low, the freight index of containers and dry bulk has exceeded Level before the epidemic. From the perspective of the "Belt and Road" foreign investment and contracted engineering business, the non-financial direct investment.

\section{Policies}

\subsection{Chinese Internal Policies}

The "one belt one road" is a magnificent strategic decision for China, which is a large open economy. The execution of this project needs the coordination and support of various macroeconomic (and other) policies to take place. 
The government can use fiscal policies, which include but not limited to increase government spending onto infrastructures, such as roads, bridges, ports, and wharves. Secondly, with the help of monetary policy, China can elevate the globalization of CNY. Thirdly, the trading coordination policies will be implemented via improving the level of trade liberalization and facilitation, promoting trade transformation and upgrading. It also accelerates the process of investment facilitation, expands mutual investment areas, explore sand establishs new models of investment cooperation, and carries out communications and cooperation in multiple fields such as culture. Fourthly, customs from different nations will have to coordinate together to maintain trade security and convenience, ensure the smooth flow of goods and the free movement of people. Last but not least, transportation will be built in terms of providing convenience. In addition to major transportation projects and node construction, the internationalization and integration of transportation services is also the focus of the "one Belt one Road" initiative [7].

\subsection{Chinese International Projects}

It is worth mentioning that the Cooperation between China and Central and Eastern European Countries ("16+1 cooperation") project injects new impetus into the economic recovery of Central and Eastern European countries. During the 9-year time period of this cooperation, China established cooperation with Central and Eastern European Countries in more than 20 fields. Now, the "16+1 cooperation" has entered a maturity period__economic data has shown that this project validly push the economic integration of European countries as well as the economic development of central and eastern European countries [8].

The pandemic did not stop this project from running. In terms of resumption of work and production, China actively promoted the resumption of work and production of major " $16+1$ cooperation" projects, and the reopening of China-Europe trains has actively promoted the resumption of local production. The project is actively looking for new post-pandemic opportunities. They can establish new chances of cooperation in terms of public health (such as the vaccine). It also launches a new "engine" with digital economic cooperation, which leads the new development with green economic cooperation (that is concerning the emission of carbon dioxide). Therefore, they seek for new cooperation chances during holding of winter Olympics, 2022 [9].

\section{Problems and solutions}

\subsection{Problems of BRI}

\subsubsection{Lack of Attraction to Private Capital}

Infrastructure construction projects for countries along the Belt and Road have a huge demand for financing. To fully fund the total BRI project volume of estimated USD 4 to 8 trillion, diverse funding channels such as BRI bonds, private capital investment and public-private partnerships (PPP) but also State-Owned Enterprise (SOE) investment will be crucial for the success of the Initiative. According to the Asian Development Bank (ADB), Asia faces an infrastructure funding gap of estimated USD 26 trillion through 2030. However, loan support provided by financial institutions is far from being sufficient. Taking the Asia-Pacific region as an example, during the year 2010 and 2020, countries will need to invest an average of US $\$ 800$ billion annually in infrastructure construction and maintenance if they are to maintain their current growth rate [10]. The infrastructure sectors that most urgently need loan support are power facilities, communications facilities and roads, which require respectively US $\$ 400$ billion, US $\$ 230$ billion and US $\$ 110$ billion annually. However, the current funding scale of multilateral development banks for infrastructure construction is too small to meet the sectors' demand. For example, the Asian Development Bank provided only US \$15 billion for infrastructure projects in the region in 2014 [11].

Cross-border infrastructure projects are mostly risky, making them much less attractive to private capital. The potential risks of the projects mainly include political risks, return risks, risks of exchange 
rate fluctuation, etc. Political risks are the major risks for transnational projects. The BRI Infrastructure construction projects are participated by many countries together. National strength and stable policies are the key to the smooth-going of the BRI infrastructure construction projects. Firstly, some countries along the Belt and Road are politically unstable, economically backward, with severe ethnic and religious conflicts and complicated geopolitical conditions. For the Political Risks along the Belt and Road, Zhang et al. did a detailed analysis in the article Spatial Big Data Analysis of Political Risks along the Belt and Road [12]. Secondly, the policy continuity of the country in partnership affects the implementation of the projects, as political continuity and stability is crucial for the long-term cooperation between government and enterprise. If the host government pays too much attention to the small businesses, interferes in the affairs of the small businesses by not only participating in but also supervising the projects, the scope of responsibilities could be blurred, thus affecting the standard construction of the projects. Return risk is another main risk infrastructure construction projects have to consider. At present, the BRI infrastructure construction projects are mainly in the field of transportation, oil and gas, hydropower and photovoltaic infrastructure. From the perspective of cost and return, the return rate of infrastructure investment is low. What's worse, the risk of exchange rate fluctuations will change the book capital and liabilities in the process of project partnership, and the calculation of cost is could be easily biased and distorted in one way or another.

Other reasons such as a lack of financing patterns, high financing cost and imperfect financing market also hinder investment from private capital. On the one hand, there are relatively few financing patterns, and mostly financing for overseas projects rely on sovereign borrowing, with energy and resources as collateral. What's more, due to control on capital account and other political reasons, it is difficult for domestic enterprises and projects to get financed in the international capital market. On the other hand, the financing cost on China's financial market is high, and the interest rate for policy loans is even higher than that of major foreign countries. Some commercial banks support the BRI infrastructure construction by issuing concessional loans. However, due to their complicated procedures of approval and strict restrictions on the direction of capital flow, stringent interest rate and terms, the utilization of concessional loans is greatly limited. At present, financing for BRI crossborder infrastructure projects is dominated by governments and international organizations. Investment products and projects are suitable for private capital participation and have not been developed. The lack of secondary markets flaws the withdrawal mechanism of private capital participating in infrastructure construction. Investment on infrastructure construction projects can take a long time. In the absence of a secondary market, private capital cannot exit at the right time and does not favor infrastructure construction projects.

\subsubsection{Tariff Barriers}

The trade barriers of some countries along the Belt and Road hinder the free trade cooperation between the two sides. Business indicators indicate that in Central Asia, for example, it can take up to fifty days to comply with all procedures to import goods. It takes less than ten in G7 countries. This is why policy reform and cooperation particularly free trade agreement must complement infrastructure projects to boost connectivity. Tariff reduction stipulated in free trade agreement will gradually make trade barriers less common, because as long as the origin of goods for bilateral or multilateral import and export is the country that signed the agreement, trade must be carried out in accordance with the tariff stipulated in the agreement [13]. However, the still ineffective and inefficient free trade agreement negotiating and signing among countries along the Belt and Road is no good news to the promotion of international trade and investment. Overall, the number of bilateral and regional free trade agreements is still unsatisfactory. Countries still need to step up the negotiating and signing of free trade agreements, facilitate the flow of goods and services within the region, and improve in aspects such as the coordinated development of regional economy and international coordination on tariffs. At the same time, countries along the Belt and Road have not yet agreed on a unified tariff dispute settlement mechanism, and only a small number of arrangements on regional tariff coordination are in place. Bilateral free trade agreements, multilateral free trade agreements and 
tax arrangements between and among them often only provide for diplomatic consultation mechanisms in principle, without specific dispute settlement mechanisms. Even the rules-based regional trade agreements generally do not set up special appellate body or enforcement supervision body.

\subsection{China's Solutions}

\subsubsection{Use the PPP Model to Introduce Private Capital}

Public-Private-Partnership (PPP) is a partnership between private sector entities that encourages them to work with the government to get involved in infrastructure constructions. The very basic procedures of PPP mode are as follows: the government temporarily transfers the projects controlled by it to the private sector entity usually for the term of the arrangement; the private sector entity builds, extends or operates the project, and the government specifies the operating features of the project; tervices are provided by the private sector entity using the project for a defined period of time usually with restrictions on operations and pricing. The private sector entity agrees to transfer it to the government with or without payment at the end of the arrangement [14].

As for the project operation, the introduction of PPP mode can absorb private capital, so as to reduce the dependence of BRI infrastructure construction on the government in terms of financing, construction, operation and management, especially on fiscal revenue. After the private capital enters, the project company would be established with the government. The company is more knowledgeable and professional about infrastructure construction than the government. This makes the government not to focus most of its efforts in a certain infrastructure construction. Instead, the government can on the basis of the comprehensive and comparative analysis of the various projects select different specific PPP modes. Under the premise of the normal operation of the financing chain, the free transformation of capital and regulatory power in space and time can be realized, which can help the government to invest sufficient capital in the more important infrastructure construction and the more reasonable allocation of infrastructure investment funds would be brought into reality. The introduction of PPP mode can also be used as an opportunity for developing countries within BRI to improve their market economy. And a benign and reasonable market economy system can be formed under the catalysis of the private sector gradually entering the public domain.

\subsubsection{Giving Full Play to the Role of AIIB}

As for the speed of funding, AIIB will draw on the experience of multilateral development banks, shorten the approval time of project funds under the principle of high efficiency, and provide funds and technical assistance to underdeveloped regions in a timely manner. AIIB projects only need to go through five main procedures from identification to implementation. In just one year after its establishment, the bank has implemented nine financial assistance projects with a total amount of us $\$ 1.73$ billion [15]. In contrast, a loan procedure of the World Bank needs to go through 50 lengthy formal procedures from approval to implementation, taking an average of 12 to 16 months, which is difficult to meet the urgent needs of developing countries. Through a more streamlined and efficient approval process, AIIB can make funds more quickly invested in infrastructure construction projects in developing countries, so that aid resources can truly cater to the urgent needs of developing countries.

In terms of the amount of funding, many of the AIIB's members have strong financial capabilities and extensive experience in managing international institutions. With the funds and talents of these countries as guarantees, the AIIB has won the trust of international investors because of its strong capital, sound policy system, clear development strategy and high-quality management. This means that AIIB can raise more funds in the national capital market at a lower cost to provide assistance to underdeveloped regions, so as to better achieve the goals of economic development and poverty reduction. In addition, AIIB is becoming a bridge for international development financing. Through cooperation with other multilateral development banks, AIIB can introduce more capital, technology and management experience into infrastructure construction in Asia. Six of the nine financing projects 
approved by the AIIB in 2016 were co-financed with other multilateral development banks. From this perspective, the AIIB has fully mobilized the forces of all parties, strengthened cooperation among multilateral development banks and injected more resources into regional development.

\section{Conclusion}

The AIIB has played a very important role in the One Belt One Road project, not only raising funds, but also promoting the development of various projects. Various projects including multinational cooperation projects have also promoted the development of the Belt and Road Initiative. Although tariff barriers, trade barriers, and political factors exist, there are reasonable ways to solve them. Generally speaking, the development prospects of the AIIB and the Belt and Road Initiative are still very positive.

\section{References}

[1] Huang, Y. (2016). Understanding China's Belt \& Road Initiative: Motivation, framework and assessment. China Economic Review, 40, 314 - 321.

[2] Callaghan, M., \& Hubbard, P. (2016). The Asian Infrastructure Investment Bank: Multilateralism on the Silk Road. China Economic Journal, 9 (2), 116 - 139.

[3] Mishra, R. (2016). Asian Infrastructure Investment Bank: An assessment. India Quarterly: A Journal of International Affairs, 72 (2), 163 - 176.

[4] Ren, X. (2016). China as an institution-builder: The case of the AIIB. The Pacific Review, 29 (3), 435 442.

[5] Ohashi, H. (2018). The belt and road initiative (BRI) in the context of China's opening-up policy. Journal of Contemporary East Asia Studies, 7 (2), 85 - 103.

[6] Chan, H. K., Dai, J., Wang, X., \& Lacka, E. (2019). Logistics and supply chain innovation in the context of the belt and road initiative (BRI). Transportation Research Part E: Logistics and Transportation Review, 132, $51-56$.

[7] The office of leading group for advancing the Belt and Road Initiative. (2019). One belt, one road initiative, progress and contribution.

[8] Grieger, G. (2018). China, the 16+1 Format and the EU. European Parliamentary Research Service.

[9] Szczudlik, J. (2019). Seven Years of the 16+1: An Assessment of China's 'Multilateral Bilateralism' in Central Europe. Ifri.

[10] Bhattacharyay, B. (2010). Estimating demand for infrastructure in Energy, transport, telecommunications, water, and sanitation in Asia and the pacific: 2010-2020. SSRN Electronic Journal.

[11] Asian Development Bank. (2020, July 22). ADB Annual report 2014. Asian Development Bank. Retrieved September 26, 2021.

[12] Zhang, C., Xiao, C., \& Liu, H. (2019). Spatial Big Data Analysis of political risks along the belt and road. Sustainability, 11(8), 2216.

[13] Aberg, J. H. S. (n.d.). A struggle for leadership recognition: The AIIB, reactive Chinese assertiveness, and Regional Order. Contemporary Chinese Political Economy and Strategic Relations: An International Journal. Retrieved September 28, 2021.

[14] Grimsey, D., \& Lewis, M. K. (2002). Evaluating the risks of Public Private Partnerships for Infrastructure Projects. International Journal of Project Management, 20 (2), 107 - 118.

[15] Home - 2016 AIIB Annual Report and financials. Home - 2016 AIIB Annual Report and Financials. (n.d.). Retrieved September 26, 2021. 